\title{
Comparison of Strategies for Thermal Storage Operation to Increase the Share of Renewable Energy in District Heating Systems
}

\author{
Nicolas Witte-Humperdinck \\ Chair of Energy Technology \\ University of Duisburg-Essen \\ Duisburg, Germany \\ nicolas.witte@uni-due.de
}

\author{
Christian Thommessen \\ Chair of Energy Technology \\ University of Duisburg-Essen \\ Duisburg, Germany \\ christian.thommessen@uni-due.de
}

\author{
Florian Nigbur \\ Energy System Analysis \\ Lagom.Energy GmbH \\ Duisburg, Germany \\ nigbur@lagom.energy
}

\author{
Jan Scheipers \\ Consulting \\ Lagom.Energy GmbH \\ Duisburg, Germany \\ scheipers@lagom.energy
}

\begin{abstract}
Combined heat and power (CHP) plants are the main supply source in Germany's district heating systems (DHS). Usually the generated power is fed into the power grid. Because CHP plants normally come along with thermal storages the heat supply operation is flexible, so that the electricity production can be optimized, e.g. by producing at times with attractive in-feed tariffs. However, in the course of the necessary transformation of all energy systems, renewable energy sources are increasingly being integrated into existing infrastructures. DHS operators are also involved in the expansion of renewable heat, e.g. by implementing solar thermal plants or large-scale heat pumps. In order to increase the share of renewable energy in DHS, thermal storage operation becomes essentially important. On the one hand, as much renewable heat as possible should be used or stored and on the other hand, CHP plants must run and fill $t$ he $s$ torage if $t$ he $r$ ecoverable a mount $f$ rom $t$ he electricity sector is economically justifiable. $B$ oth i mply $l$ ess $f$ ree storage capacity, whereas the chronological harmonization of loading and unloading plays an important role. The contribution of this paper is an analysis on different operation strategies for thermal storages to increase the share of renewable energy in urban DHS. Furthermore, the influence of heat load prediction and electricity price forecasting on thermal storage operation is derived. Results of a comparison of typical storage operation methods on a use case show that under the current legal framework conditions a flexible $t$ hermal $\mathrm{s}$ torage $\mathrm{o}$ peration i s e ligible $\mathrm{t} \mathrm{o} \mathrm{m}$ eet several targets, i.e. increasing the share of renewable energy, securing the supply of heat to the DHS and ensuring an economic operation of the entire portfolio.
\end{abstract}

Keywords-Cogeneration, District Heating, Renewable Heating, Sector Coupling, Thermal Storage Operation

\section{Challenges of the German EnERGy transition}

As part of the German Energy Transition, renewable energies are increasingly being integrated into the energy supply. The focus here is particularly on the electricity sector: the share of renewable energies in Germany's gross electricity consumption was increased from $3.4 \%$ to $37.8 \%$ in the years 1990 to 2018 [1]-[3]. However, a large part of the German primary energy demand is attributable to the heating sector. Although the heating sector has great potential for saving $\mathrm{CO}_{2}$ emissions, the share of renewable energies in the heating supply has stagnated at around $14 \%$ since 2012 [3]. For this reason, the share of renewable energies in the heat supply is to be significantly increased in future, among other things by new subsidy programmes of the Federal Government. District heating systems (DHS) offer a possible solution, as they create the possibility of decoupling heat generation and heat consumption spatially. In this way, renewable heat can be transported to densely populated urban areas where either no renewable heat sources are available or renewable heat generators cannot be realized or are difficult to realize due to lack of space. Especially in densely populated urban agglomerations, different land uses are in competition [4].

\section{COMPONENTS OF HEAT SUPPLY SYSTEMS}

A large part of the German district heating systems is supplied by combined heat and power (CHP) plants. In 2018, the share of CHP plants in the total heat input was about $80 \%$ [5]. The electricity generated in the CHP process is fed into the grid or used for self-supply. In addition to the CHP plants, such systems are also equipped with boilers to cover peak loads and thermal storages to offer the possibility to buffer the heat when it is not used directly (Figure 1).

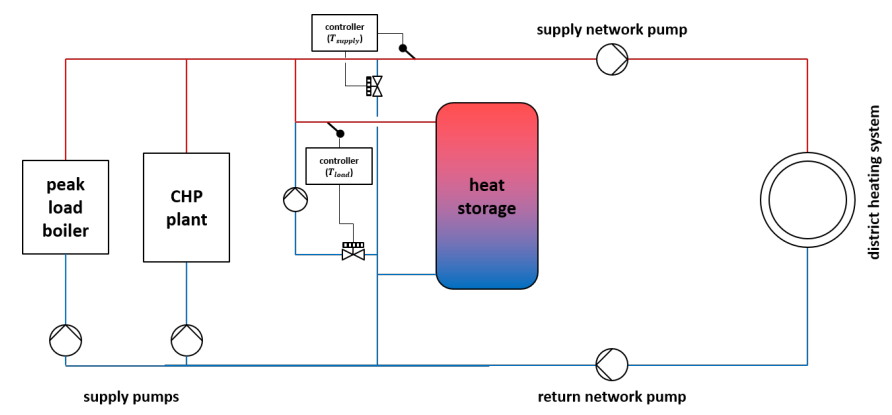

Fig. 1. Representation of traditional energy supply components in district heating systems.

In the case of locally or regionally operating energy supply companies, which are the focus of the following considerations, the stock exchange electricity price is usually used as the reference variable for the operation of the CHP plants. If a high revenue can be achieved from the electricity fed into 
the power grid, the CHP plants are operated. This requires a sufficiently large heat sink so that the CHP plant can be operated at maximum (cost) efficiency. If there is only a low heat demand by the consumers of the heat network, a thermal storage offers a further degree of freedom for the operation of the CHP plant [6].

Depending on the heat storage capacity, the operation of CHP plants can be ensured over longer periods of time even if (in the extreme case) there is no heat demand from the consumers. Existing systems are accordingly designed with a focus on efficient operation of the CHP plant as their central element (cf. [7]-[10]). A characteristic feature of many renewable energy generation plants is fluctuating generation. The prognosis of the fluctuating generation of renewable energy plants (especially wind and solar energy) is usually associated with great inaccuracies. Moreover, due to high outside temperatures in the summer it is often the case, that solar thermal heat generation is mainly used when the heat demand is low. In order to nevertheless achieve a high proportion of renewable energies in the heat supply, the heat storage system is therefore of central importance (cf. [11], [12]).

In addition to normal heat storages which are used to buffer heat for a short period, seasonal heat storages are also implemented in the heating sector, with which heat generation and heat consumption can be decoupled over several months (cf. [13]-[15]).

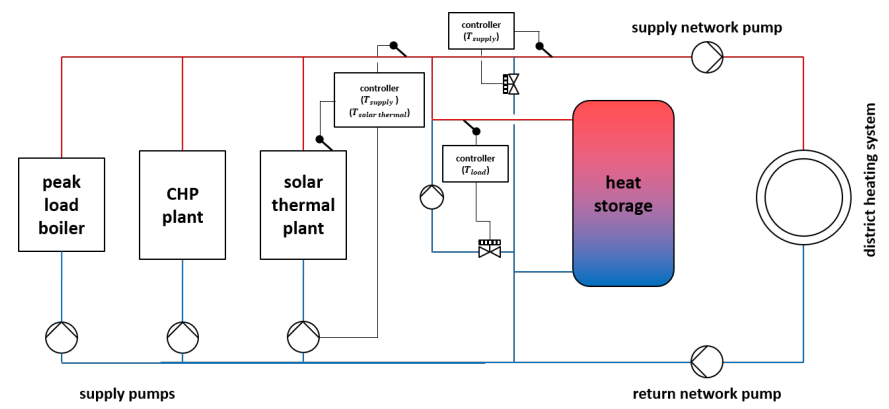

Fig. 2. Representation of an improved energy supply for district heating systems considering integrated renewable energy.

The integration of renewable heat generators into existing systems is correspondingly linked to the problem that the storage strategy was developed considering the operation of the CHP plants, as these had previously represented the central element of the described energy systems. Without an adjustment of the heat storage operation strategy (essentially the loading and unloading phases), it may happen that the heat storage has been filled by the CHP plants and no free storage capacity for renewable heat is available, which leads to a low heat coverage ratio of the renewable heat generators. This problem arises mainly with non-regulable solar thermal systems, which are the focus of the following analysis. An obvious solution is the use of an additional heat storage only for the solar thermal systems. However, in densely populated, urban agglomerations there is rarely sufficient space available, which is why the installation of an additional heat storage to buffer the fluctuating renewable heat generated is rarely possible.

\section{SOLUTION APPROACH}

One possible solution is to modify the conventional heat storage operation strategy, which focuses on the CHP plant. In the following paper, in addition to the initial strategy, four further options for structured loading and unloading of heat storages are presented, with the help of which the heat coverage ratio of the renewable heat generators is to be increased without an additional storage system. In general, this research is based on the approach proposed in [16].

\section{A. Storage operation strategy 1 (reference)}

The initial strategy is used for controllable cogeneration plants. The heat storage serves as an additional heat sink and is always loaded by the CHP unit when the heat demand of the grid as a heat sink is not sufficient for the operation of the CHP unit. It is discharged to reduce the operating times of the peak load boiler and to reduce the start-stop operation of the CHP plant.

\section{B. Storage operation strategy 2}

In the first modification of the initial strategy, storage operation strategy 2 limits the loading phase to periods with high solar radiation. As can be seen in figure 3, storage charging is only possible between 07:00 a.m. and 09:00 p.m.

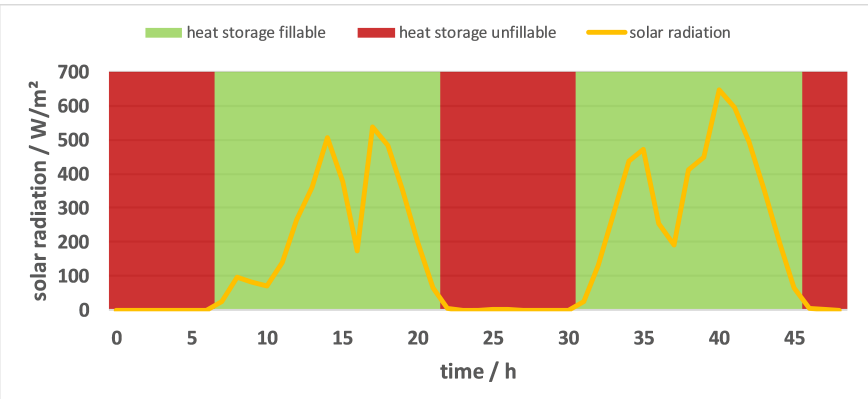

Fig. 3. Representation of storage operation strategy 2 .

\section{Storage operation strategy 3}

Storage operation strategy 3 combines strategies 1 and 2. In storage operation strategy 3 , strategy 2 is not used throughout the year but for a fixed period of time. In the other months, the heat storage is operated using strategy 1 . The switchover time is adjustable. For the following case study, the switch from strategy 1 to strategy 2 takes place in the middle of March and reverses in the middle of September.

\section{Storage operation strategy 4}

A concrete control of the heat storage depending on the heat demand is done by means of strategy 4 . As soon as the heat storage filling level is sufficient to cover the heat demand, the heat storage is discharged. Loading by controllable generation 


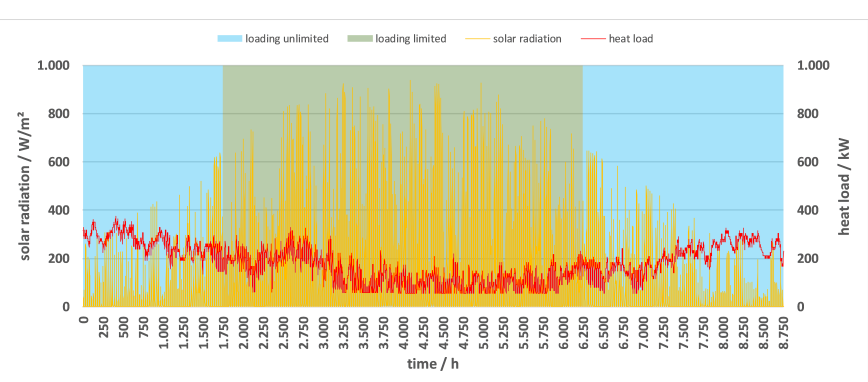

Fig. 4. Representation of storage operation strategy 3.

plants is not possible in this unloading phase. This strategy increases the loading and unloading cycles of the thermal storage accordingly. To increase the solar heat coverage ratio, the integration of solar thermal heat is possible without any restrictions.

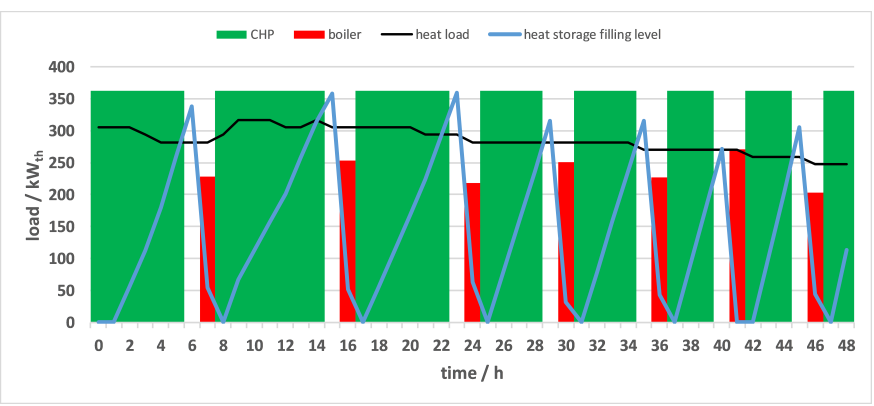

Fig. 5. Representation of storage operation strategy 4 .

\section{E. Storage operation strategy 5}

Finally, the heat storage is controlled in strategy 5 by means of minimum and maximum fill levels. Thus, the storage is charged in a charging phase up to a filling level that is to be fixed (in the following $100 \%$ ). If this filling level is reached, the heat storage is discharged in a discharge phase up to a specified minimum filling level (in the following $10 \%$ ). In the discharge phase, charging by controllable generating plants is not possible. Again, to increase the solar heat coverage ratio, no restrictions apply to the integration of solar thermal heat.

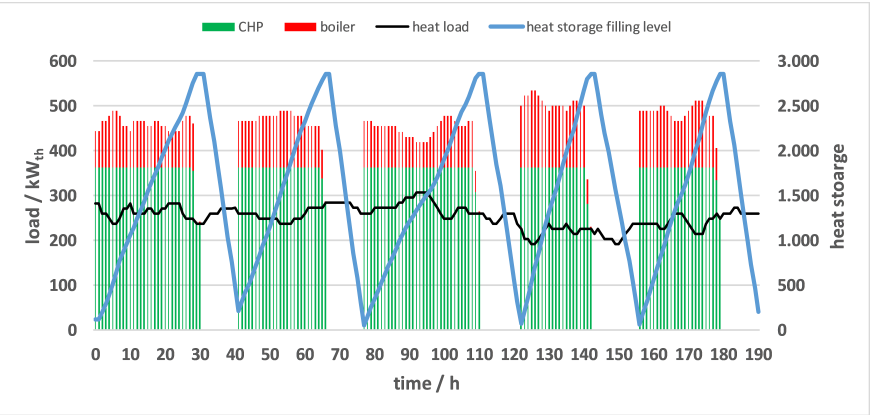

Fig. 6. Representation of storage operation strategy 5 .

\section{Application to a REAl USE-CASE}

In the following, the five heat storage operation strategies are to be applied to a real neighbourhood in order to be able to analyse the influence on the heat coverage of the controllable and fluctuating heat generation plants. Therefore, an urban quarter in the Ruhr area with 22 residential buildings, whose heat supply is provided by a third-generation heat network, is considered (cf. [17], [18]). The consumers are exclusively residential properties and mainly apartment buildings. The supply temperature of the heating network is $75{ }^{\circ} \mathrm{C}$ all year round with a target temperature spread at the consumers of $25 \mathrm{~K}$. The minimum network load to be operated, which is adjusted on the basis of the mass flow rate, is about $54 \mathrm{~kW}$ (due to the provision of domestic hot water, the network load does not fall below the domestic hot water base). The annual maximum load is about $375 \mathrm{~kW}$ and occurs in the hours with the lowest outside temperature. The operation of the heat generation plants is essentially based on the required grid feedin, which is determined by the heat demand of the consumers and the heat losses during distribution. In the case of CHP plants, the stock market price of electricity is also considered as a further reference variable. This means that the CHP unit can only be operated if the stock exchange electricity price exceeds a certain border price. The amount of this price is chosen depending on the marginal costs of the CHP plant. For this case study, the stock exchange price for base-load electricity from 2019 is taken into account [19], [20]. In order to show the influence of CHP plants on the solar heat coverage ratio, a CHP plant whose thermal output corresponds to about $50 \%$ of the peak load is considered as well as a significantly more powerful plant. The performance data of the plants can be found in table I.

TABLE I

ENERGY SUPPLY DATA OF CHP PLANTS

\begin{tabular}{|c|c|c|c|c|c|c|}
\hline \multirow[t]{2}{*}{ CHP } & \multicolumn{2}{|c|}{$100 \%$ load / kW } & \multicolumn{2}{|c|}{$75 \%$ load / kW } & \multicolumn{2}{|c|}{$50 \%$ load $/ \mathrm{kW}$} \\
\hline & electricity & heat & electricity & heat & electricity & heat \\
\hline unit 1 & 140 & 212 & 100 & 165 & 85 & 147 \\
\hline unit 2 & 238 & 363 & 179 & 298 & 119 & 220 \\
\hline
\end{tabular}

A sensitive heat storage with a capacity that roughly corresponds to the heat requirement of a winter weekend is used as a heat storage. For comparison purposes, this capacity is not adjusted despite the integration of renewable solar thermal heat generators.

The extension of this system to include renewable heat generators is based on vacuum tube collectors, whereby data from the collector VTK 1140/2 from the company Vaillant based on the published Solarkeymark certification were taken into account [21]. A collector field with a surface area of $2,400 \mathrm{~m}^{2}$ is considered, which results in a gross collector surface area of $1,200 \mathrm{~m}^{2}$ at a land use factor of 0.5 (cf. [22], [23]), which is usual for solar thermal systems. Since the heating network is operated with a constant supply temperature of $75^{\circ} \mathrm{C}$, the integration of solar thermal heat is only possible when the collector temperature, which is determined hourly, 
exceeds the network supply temperature plus the degree of efficiency of the heat exchanger of $5 \mathrm{~K}$. Accordingly, the solar thermal systems can only be used from a collector temperature of at least $80{ }^{\circ} \mathrm{C}$. Both outside temperatures and direct and diffuse solar radiation in hourly resolution are taken from the data of the German Meteorological Service (Deutscher Wetterdienst - DWD) at the heating network site [24]. The results of the simulation of the plant operation for conventional supply by means of a CHP plant and peak load boiler are shown in table II.

TABLE II

SIMULATION RESULTS OF REFERENCE SCENARIO

\begin{tabular}{|c||c|c|}
\hline CHP & unit 1 & unit 2 \\
\hline full load hours & 4,324 & 3,889 \\
\hline operating hours & 4,356 & 4,000 \\
\hline starts & 484 & 611 \\
\hline heat coverage ratio / \% & 54.55 & 87.90 \\
\hline fuel / MWh & 1,677 & 2,627 \\
\hline fuel (boiler) / MWh & 751 & 214 \\
\hline
\end{tabular}

By taking the (day-ahead) stock exchange electricity prices into account as an operation criterion for CHP plants, the heat coverage rate of CHP unit 1 (medium load unit) is less than $60 \%$. Despite a similar number of full-load hours, CHP unit 2 can meet almost $88 \%$ of the heat demand, which is due to its higher thermal output. With a $\mathrm{CO}_{2}$ emission factor of natural gas of $201 \mathrm{~g} / \mathrm{kWh}$ [25], the $\mathrm{CO}_{2}$ emission from the operation of the supply facilities, excluding an electricity credit for electricity generated in CHP operation, is 1,488 t/a at CHP unit 1. The operation of CHP unit 2 results in $\mathrm{CO}_{2}$ emissions of $571 \mathrm{t} / \mathrm{a}$.

Figure 7 shows the heat storage filling level during the course of the year when using the various CHP plants. It is clear that the heat storage is filled completely early in the year without the control of the storage operation (correspondingly using storage operation strategy 1), especially when using the high-performance CHP plant. Using CHP unit 2, the annual average heat storage filling level is almost $54 \%$ (almost $10 \%$ with CHP unit 1). Especially in the low-load summer months, the heat storage is often completely filled by the CHP unit.

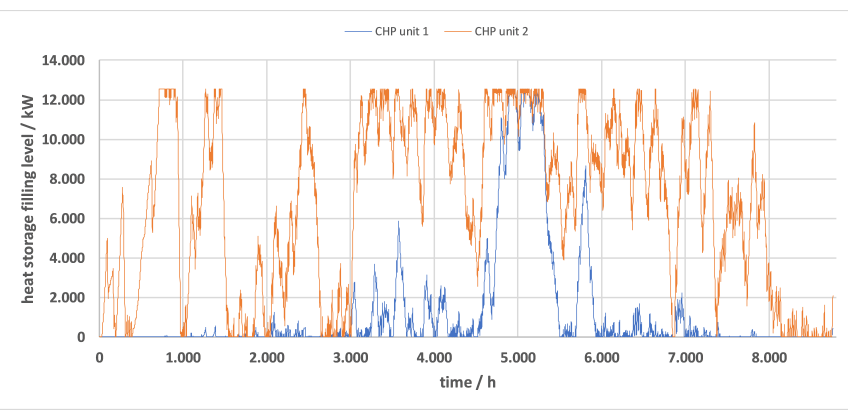

Fig. 7. Simulated storage levels for several CHP units.

The integration of solar thermal heat is severely limited by the permanently increased filling level and the partial complete filling of the heat storage in the summer months. The four other heat storage operation strategies are intended to remedy this situation. If a solar thermal plant with a gross collector area of $1,200 \mathrm{~m}^{2}$ is integrated into the system with only one central heat storage, the efficiency of the overall system varies greatly depending on the heat storage operation strategy used.

Table III shows the simulation results for the highperformance CHP unit 2 (results of CHP unit 1 can be found in the appendix). The initial heat storage strategy leads to a solar heat coverage ratio of $14.84 \%$. By adapting the heat storage operation strategy, a higher solar heat coverage ratio can be achieved in each of the variants presented, provided that a central storage system is used. The greatest effects are achieved by using storage operation strategy 4 , where the highest solar coverage ratio is achieved. However, it must be critically considered that, with the limitation of the operation of the CHP plants, the share of boiler heat in the heat network increases in addition to the solar heat coverage ratio. This is due to the fact that there are often times when the generation of the solar thermal plants and the heat storage filling level are not sufficient to fulfil the heat supply task, while at the same time limiting CHP plant operation. Accordingly, it is imperative to use the boiler.

TABLE III

SOME RESULTS FOR CHP UNIT 2

\begin{tabular}{|c|c|c|c|c|c|}
\hline CHP unit 2 & \multicolumn{2}{|c|}{ strategy 1} & \multicolumn{2}{|c|}{ strategy 2} & strategy 3 \\
\hline full load hours & \multicolumn{2}{|c|}{3,391} & \multicolumn{2}{|c|}{3,212} & 3,314 \\
\hline operating hours & \multicolumn{2}{|c|}{3,521} & \multicolumn{2}{|c|}{3,415} & 3,447 \\
\hline starts & \multicolumn{2}{|c|}{624} & \multicolumn{2}{|c|}{525} & 542 \\
\hline heat coverage ratio (CHP) / \% & \multicolumn{2}{|c|}{76.16} & \multicolumn{2}{|c|}{72.69} & 74.49 \\
\hline heat coverage ratio (boiler) / \% & \multicolumn{2}{|c|}{9.04} & \multicolumn{2}{|c|}{11.09} & 9.44 \\
\hline heat coverage ratio (solar) /\% & \multicolumn{2}{|c|}{14.84} & \multicolumn{2}{|c|}{16.21} & 16.11 \\
\hline fuel $(C H P) / M W h$ & \multicolumn{2}{|c|}{2,294} & \multicolumn{2}{|c|}{2,183} & 2,243 \\
\hline fuel (boiler) / MWh & & 60 & & 196 & 167 \\
\hline \multicolumn{2}{|l|}{ CHP unit 2} & \multicolumn{2}{|c|}{ strategy 4} & \multicolumn{2}{|c|}{ strategy 5} \\
\hline \multirow{2}{*}{\multicolumn{2}{|c|}{$\begin{array}{l}\text { full load hours } \\
\text { operating hours }\end{array}$}} & \multicolumn{2}{|c|}{1,859} & \multicolumn{2}{|c|}{2,882} \\
\hline & & \multirow{2}{*}{\multicolumn{2}{|c|}{$\begin{array}{c}1,859 \\
839\end{array}$}} & \multicolumn{2}{|c|}{2,882} \\
\hline \multicolumn{2}{|l|}{ starts } & & & \\
\hline \multicolumn{2}{|c|}{ heat coverage ratio (CHP) /\% } & \multicolumn{2}{|c|}{41.49} & 64 & \\
\hline \multicolumn{2}{|c|}{$\begin{array}{l}\text { heat coverage ratio (boiler) / \% } \\
\text { heat coverage ratio (solar) / \% }\end{array}$} & \multicolumn{2}{|c|}{36.22} & \multicolumn{2}{|c|}{17.30} \\
\hline \multirow{2}{*}{\multicolumn{2}{|c|}{$\frac{\text { heat coverage ratio (solar) /\% }}{\text { fuel }(\mathrm{CHP}) / \mathrm{MWh}}$}} & \multicolumn{2}{|c|}{21.97} & \multicolumn{2}{|c|}{18.82} \\
\hline & & \multirow{2}{*}{\multicolumn{2}{|c|}{$\frac{1,250}{641}$}} & \multicolumn{2}{|c|}{1,933} \\
\hline \multicolumn{2}{|l|}{ fuel (boiler) / } & & & 3 & \\
\hline
\end{tabular}

On the basis of the level curve shown in figure 8 when using the powerful CHP unit 2 for the various heat storage operation strategies, it is clear that the large number of loading and unloading cycles in strategy 4 lead to continuously lower heat storage filling levels, which can reduce the heat losses of the storage. Furthermore, this operating strategy enables the realization of storage facilities with lower capacity despite the simultaneous integration of heat from conventional and fluctuating renewable generation plants.

The integration of solar thermal heat leads to a reduction in fuel requirements, regardless of the storage operation strategy. This reduction is most pronounced in the case of storage 


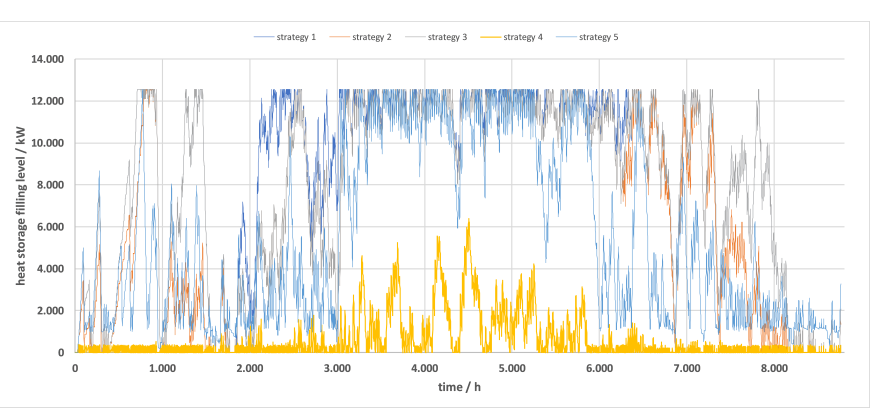

Fig. 8. Simulated storage levels for the powerful CHP unit.

operation strategy 4 , which is due to the severe restriction of the CHP plant operation.

However, it should be noted here that the highly efficient, coupled generation of electricity and heat in the CHP process was not taken into account in this case and that the reduction in fuel requirements is not only due to the high solar heat coverage ratio but also to the high proportion of boiler heat (the boiler efficiency equals $90 \%$ ). Particularly against the background of the energy system transition, a high degree of heat coverage by simple boiler firing should not be aimed for.

\section{CONCLUSION AND OUTLOOK}

The consideration of the heat sector plays an important role both for achieving the goals of the German energy system transition and for the international climate targets. By integrating renewable energies into the heating sector, $\mathrm{CO}_{2}$ emissions from decentralized combustion plants can be reduced and the primary energy requirement and use of conventional fuels in the heating sector can be decreased. Heating networks are a good way of distributing renewable heat in urban, densely populated agglomerations, as they decouple heat generation and heat consumption spatially.

If existing, conventional district supply systems are extended by renewable heat generators, it is essential to adapt the operating mode of the systems so that conventional and non-controllable, renewable heat generators do not restrict each other in their operation. In systems with a central heat storage, the heat storage represents a central control variable. In conventional systems, the heat storage is regarded as a heat buffer option for making plant operation more flexible and to prolonging it as well. But when integrating fluctuating, renewable heat generators, the storage operating strategy must be adapted. In the context of this contribution, four further variants were presented in addition to the conventional heat storage operation strategy, with the help of which the heat coverage ratio of the regenerative, non-controllable heat generators should be increased. In addition to a time limitation of the heat storage loading phases during the course of the day and the year (strategy 2 and strategy 3 ), the use of many short-term loading and unloading cycles as well as constant loading and unloading phases was considered (strategy 4 and strategy 5).
For practical evaluation, an urban agglomeration with a district heating network was considered in a case study. For a comparison, the heat supply of the 22 residential units was based on conventional CHP plants in combination with a heat storage and a peak load boiler. In addition to the heat requirement of the heating network based on the requirements of the consumers and the heat losses of the grid, the stock exchange electricity price was also used as a reference variable for the operation of the CHP plants. The heat storage was used to buffer the heat from the CHP plant (temporary increase of the heat sink, strategy 1). The consideration of the heat storage filling level in the course of the year has shown that with the storage operation strategy 1 , a complete filling of the heat storage occurs particularly in the load-weak months in the summer time. When integrating solar thermal heat, this storage filling should be avoided so that high coverage rates of renewable heat generators can be achieved.

Another heat supply solution was the expansion of the existing system by a solar thermal plant with a gross collector area of $1,200 \mathrm{~m}^{2}$. If the storage operating strategy is not adapted, the fuel requirement can be reduced, but it is not possible to achieve a high solar heat coverage ratio. In all four strategies considered, the subsequent adjustment of the heat storage operation led to an increase in the solar heat coverage ratio and to a reduction in fuel purchases (compared to the initial strategy). However, it must be critically evaluated that in addition to the solar heat coverage ratio, the heat coverage ratio of the boiler was also increased. Accordingly, a further adaptation of the heat storage operation strategies should take place against the background of a simultaneous increase in the solar heat coverage ratio and minimization of the heat coverage ratio of conventional, uncoupled heat generation. One starting point is the integration of forecasts into plant operation planning.

\section{APPENDIX}

TABLE IV

SOME RESULTS FOR CHP UNIT 1

\begin{tabular}{|c|c|c|c|c|}
\hline CHP unit 1 & strategy 1 & \multicolumn{2}{|c|}{ strategy 2} & strat \\
\hline full load hours & 3,962 & \multicolumn{2}{|c|}{3,849} & 3,8 \\
\hline operating hours & 3,988 & \multicolumn{2}{|c|}{3,904} & 3, \\
\hline starts & 548 & \multicolumn{2}{|c|}{507} & \\
\hline heat coverage ratio $(\mathrm{CHP}) / \%$ & 51.49 & \multicolumn{2}{|c|}{50.09} & \\
\hline heat coverage ratio (boiler) /\% & 31.06 & \multicolumn{2}{|c|}{31.40} & \\
\hline heat coverage ratio (solar) /\% & 17.07 & \multicolumn{2}{|c|}{18.13} & \\
\hline fuel $(C H P) / M W h$ & 1,529 & \multicolumn{2}{|c|}{1,487} & \\
\hline fuel (boiler) / MWh & 550 & \multicolumn{2}{|c|}{555} & \\
\hline $\begin{array}{l}\text { CHP unit 1 } \\
\text { full load hours }\end{array}$ & \multicolumn{2}{|c|}{ strategy 4} & \multicolumn{2}{|c|}{ strategy 5} \\
\hline full load hours & \multirow{2}{*}{\multicolumn{2}{|c|}{$\begin{array}{l}2,873 \\
2,873\end{array}$}} & \multicolumn{2}{|c|}{3,523} \\
\hline operating hours & & & \multicolumn{2}{|c|}{3,526} \\
\hline starts & \multicolumn{2}{|c|}{450} & \multirow{2}{*}{\multicolumn{2}{|c|}{$\begin{array}{c}386 \\
45.64\end{array}$}} \\
\hline heat coverage ratio $(\mathrm{CHP}) / \%$ & \multicolumn{2}{|c|}{37.37} & & \\
\hline heat coverage ratio (boiler) / \% & \multicolumn{2}{|c|}{40.17} & \multicolumn{2}{|c|}{34.53} \\
\hline \multirow{2}{*}{$\begin{array}{c}\text { heat coverage ratio (solar) /\% } \\
\text { fuel }(\mathrm{CHP}) / \mathrm{MWh}\end{array}$} & \multicolumn{2}{|c|}{21.97} & \multicolumn{2}{|c|}{19.67} \\
\hline & \multirow{2}{*}{\multicolumn{2}{|c|}{$\begin{array}{l}1,107 \\
7111\end{array}$}} & 1,3 & \\
\hline fuel (boiler) / MWh & & & 61 & \\
\hline
\end{tabular}




\section{ACKNOWLEDGMENTS}

This work was funded by the Ministry of Culture and Science of the German state of North Rhine-Westphalia within the scope of the project "Nachhaltige Energiesysteme im Quartier" (research grant no. 321-8.03-110-116441). Furthermore, this work was funded by the European Regional Development Fund (EFRE) and the German state of North Rhine-Westphalia within the scope of the project "Intelligente Sektorenkopplung zur Reduktion von $\mathrm{CO}_{2}$-Emissionen in Energieversorgungssystemen (InSekt)" (research grant no. EFRE0801112).

\section{REFERENCES}

[1] Federal Ministry for Economic Affairs and Energy (BMWi), "Renewable Energy Sources Act (EEG 2017)," law entered into force on 21. June 2018, available online at https://www.bmwi.de/Redaktion/DE/ Downloads/E/eeg-2017-gesetz-en.pdf [accessed 09. March 2020].

[2] Federal Ministry for Economic Affairs and Energy (BMWi), "Gesetz zur Förderung Erneuerbarer Energien im Wärmebereich (ErneuerbareEnergien-Wärmegesetz - EEWärmeG)," law entered into force on 20 October 2015, available online at http://www.gesetze-im-internet.de/ bundesrecht/eew_rmeg/gesamt.pdf [accessed 09. March 2020].

[3] Arbeitsgruppe Erneuerbare Energien-Statistik (AGEE-Stat), "Time series for the development of renewable energy sources in Germany 1990 2018," 31. December 2019, available online at https://www.erneuerbareenergien.de/EE/Redaktion/DE/Downloads/zeitreihen-zur-entwicklungder-erneuerbaren-energien-in-deutschland-1990-2018-en.pdf [accessed 09. March 2020].

[4] German Environment Agency (Umweltbundesamt -- UBA), "Rural Urban Nexus - Globale Landnutzung und Urbanisierung: Integrierte Ansätze für eine nachhaltige Stadt-Land-Entwicklung," March 2019, available online at https://www.umweltbundesamt.de/sites/default/ files/medien/1410/publikationen/2019-11-08_texte_138-2019_runabschlussbericht.pdf [accessed 09. March 2020], ISSN 1862-4804.

[5] AGFW - Der Energieeffizienzverband für Wärme, Kälte und KWK e.V., "AGFW-Hauptbericht 2018," September 2019, available online at https://www.agfw.de/index.php?eID=tx_ securedownloads $\& \mathrm{p}=436 \& \mathrm{u}=0 \& \mathrm{~g}=0 \& \mathrm{t}=1583853559 \&$ hash $=$ f0c3ea86f4088772df7d182dc076469b8958b467\&file=fileadmin/user upload/Zahlen_und_Statistiken/Version_1_HB2018.pdf [accessed 09 . March 2020].

[6] C. Thommessen, A. Hipp, J. Scheipers, J. Roes, and A. Heinzel, "Multiperiod optimization for the scheduling of distributed cogeneration plants in district heating systems on the basis of residual heating costs," Proceedings of the 33rd International Conference on Efficiency, Cost, Optimization, Simulation and Environmental Impact of Energy Systems (ECOS2020), Osaka, Japan, June 29 - July 03, 2020.

[7] M. Liu, S. Wang, Y. Zhao, H. Tang, and J. Yan, "Heat-power decoupling technologies for coal-fired CHP plants: Operation flexibility and thermodynamic performance," Energy, vol. 188, December 2019, doi: 10.1016/j.energy.2019.116074.

[8] H. Wang, H. Zhang, C. Gu, and F. Li, "Optimal design and operation of CHPs and energy hub with multi objectives for a local energy system," Energy Procedia, vol. 142, pp. 1645-1621, December 2017, doi: 10. 1016/j.egypro.2017.12.539.

[9] J. Rist, M. Dias, M. Palman, D. Zelazo, and B. Cukurel, "Economic dispatch of a single micro-gas turbine under CHP operation," Applied Energy, vol. 200, pp. 1-18, August 2017, doi: 10.1016/j.apenergy.2017. 05.064 .

[10] A. Piacention, N. Duic, N. Markovska, B.V. Mathiesen, Z. Guzovic, V. Eveloy, and H. Lund "Sustainable and cost-efficient energy supply and utilisation through innovative concepts and technologies at regional, urban and single-user scales," Energy, vol. 182, pp. 254-268, September 2019, doi: 10.1016/j.energy.2019.06.015.

[11] K. Hansen, and B.V. Mathiesen, "Comprehensive assessment of the role and potential for solar thermal in future energy systems," Solar Energy, vol. 169, pp. 144-152, July 2018, doi: 10.1016/j.solener.2018.04.039.

[12] E. Guelpa, and V. Verda, "Thermal energy storage in district heating and cooling systems: A review," Applied Energy, vol. 252, October 2019, doi: $10.1016 /$ j.apenergy.2019.113474.
[13] K. Narula, F. de Oliveira Filho, W. Villasmil, and M. Patel, "Simulation method for assessing hourly energy flows in district heating system with seasonal thermal energy storage," Renewable Energy, vol. 151, pp. 12501268, May 2020, doi: 10.1016/j.renene.2019.11.121.

[14] J. Hennessy, H. Li, F. Wallin, and E. Thorin, "Flexibility in thermal grids: a review of short-term storage in district heating distribution networks," Energy Procedia, vol. 158, pp. 2430-2434, February 2019, doi: 10.1016/ j.egypro.2019.01.302.

[15] A. Rosato, A. Ciervo, G. Ciampi, M. Scorpio, and S. Sibilio, "Impact of seasonal thermal energy storage design on the dynamic performance of a solar heating system serving a small-scale Italian district composed of residential and school buildings," Journal of Energy Storage, vol. 25, October 2019, doi: 10.1016/j.est.2019.100889.

[16] N.E. Witte-Humperdinck, "Untersuchung der Auswirkungen von Einspeisung erneuerbarer Wärme auf KWK-Wärmenetze in urbanen Quartiersstrukturen," Duisburg, Germany: Universität Duisburg-Essen, 2019 [dissertation], doi: 10.17185/duepublico/70832.

[17] H. Lund, S. Werner, R. Wiltshire, S. Svendsen, J.E. Thorsen, F. Hvelplund, and B.V. Mathiesen, "4th Generation District Heating (4GDH): Integrating smart thermal grids into future sustainable energy systems," Energy, vol. 68, pp.1-11, April 2014, doi: 10.1016/j.energy. 2014.02.089.

[18] H. Lund, N. Duic, P.A. Østergaard, and B.V. Mathiesen, "Future district heating systems and technologies: On the role of smart energy systems and 4th generation district heating," Energy, vol. 165, pp. 614-619, December 2018, doi: 10.1016/j.energy.2018.09.115.

[19] Bundesnetzagentur für Elektrizität, Gas, Telekommunikation, Post und Eisenbahnen (BNetzA), "SMARD Strommarktdaten," license CC BY 4.0, available online at https://www.smard.de/home/downloadcenter/ download_marktdaten [accessed 09. March 2020].

[20] European Network of Transmission System Operators for Electricity (ENTSO-E) "Scheduled Commercial Exchanges," available online at https://transparency.entsoe.eu/transmissiondomain/r2/scheduledCommercialExchangesDayAhead/show [accessed 09. March 2020].

[21] Solar Keymark, "Annex to Solar Keymark Certificate -- Summary of EN ISO 9806:2013 Test Results," available online at http:/ www.solarkeymark.n1/DBF/PDF_Downloads/DS_721.pdf [accessed 09. March 2020].

[22] Wuppertal Institut et al., "LowEx Herten: Innovative interkommunale Wärmeversorgung für die Neue Zeche Westerholt in Herten/Gelsenkirchen.," February 2020, available online at https://epub. wupperinst.org/files/7461/7461_LowEx_Herten.pdf [accessed 09. March 2020].

[23] Ritter XL Solar, "Hocheffiziente Solarthermie als Teil der Wärmewende,“ January 2018, available online at https://www.ritter-xl-solar.de/wp-content/uploads/2018/01/Ritter XL_Solar_Imagebroschuere_Ansicht.pdf [accessed 09. March 2020].

[24] Deutscher Wetterdienst, "Testreferenzjahre (TRY)," available online at https://www.dwd.de/DE/leistungen/testreferenzjahre/testreferenzjahre. html [accessed 09. March 2020].

[25] P. Icha, and G. Kuhs, "Entwicklung der spezifischen KohlendioxidEmissionen des deutschen Strommix in den Jahren 1990 - 2016," May 2017, available online at https://www.umweltbundesamt.de/ sites/default/files/medien/1410/publikationen/2017-05-22_climatechange_15-2017_strommix.pdf [accessed 09. March 2020]. 